\section{Science $\mathcal{W}$ Directo}

Palaeogeography, Palaeoclimatology, Palaeoecology 215 (2005) 205-219
PALAEO

www.elsevier.com/locate/palaeo

\title{
Taxonomic turnover and abundance in Cretaceous to Tertiary wood floras of Antarctica: implications for changes in forest ecology
}

\author{
David J. Cantrill ${ }^{\mathrm{a}, *}$, Imogen Poole $\mathrm{e}^{\mathrm{b}, \mathrm{c}}$ \\ ${ }^{a}$ Swedish Museum of Natural History, Department of Palaeobotany, Box 50007, Stockholm 104 05, Sweden \\ ${ }^{\mathrm{b}}$ Palaeontological Museum, Oslo University, P.O. Box 1172 Blindern, N-0318 Oslo, Norway \\ ${ }^{\mathrm{c}}$ Wood Anatomy Section, National Herbarium of the Netherlands, University of Utrecht Branch, \\ P.O. Box 80102, 3585 CS Utrecht, The Netherlands
}

Received 23 February 2004; received in revised form 20 July 2004; accepted 9 September 2004

\begin{abstract}
Based on the temporal distribution, abundance, and taxonomic composition of wood floras, four phases of vegetation development are recognized through the Cretaceous to Early Tertiary of the Antarctic Peninsula: (1) Aptian to Albian communities dominated by podocarpaceous, araucarian, and minor taxodiaceous/cupressaceous conifers with rare extinct gymnosperms (Sahnioxylon). (2) Progressive replacement of these communities in ?Cenomanian to Santonian times by angiosperms, most without modern analogues. (3) Increasing dominance of angiosperms becoming important both in terms of diversity and abundance towards the mid-Late Cretaceous. (4) Modernization of the flora during the Campanian to Maastrichtian with the extinction of earlier forms, appearance of the Nothofagaceae and diversification of associated elements. These patterns broadly follow trends seen in the leaf and palynological record but with some important differences.

During the Cretaceous, conifer composition undergoes a change whereby Phyllocladoxylon-type woods increase relative to the older Podocarpoxylon forms. During the Paleocene to Eocene period, a marked extinction in wood types occurs associated with an increase in the abundance of nothofagaceous wood. Detailed examination of wood abundance and distributions from sections within Maastrichtian and Paleocene formations points to strong environmental control on taxonomic compositions. Similar differences are encountered when comparing coeval floras from different geographic regions and palaeoenvironments.
\end{abstract}

(C) 2004 Elsevier B.V. All rights reserved.

Keywords: Antarctica; Cretaceous; Tertiary; fossil wood; angiosperm; conifer

\section{Introduction}

* Corresponding author. Fax: +46 851954221.

E-mail address: david.cantrill@nrm.se (D.J. Cantrill).
Fossil wood has been known from the Antarctic regions since the 1830s (Eight, 1833). With reports of further wood localities in the Seymour Island region 
(Larsen, 1894; Sharman and Newton, 1894, 1898) and subsequent discoveries of Jurassic, Cretaceous and Tertiary plant fossils during the Swedish South Polar Expedition of 1901-1903, considerable scientific interest was aroused since these floras all pointed to a vegetated landmass in what is now an icy world. Fossil wood is widespread in Mesozoic and Tertiary sequences on the Antarctic Peninsula: remains of trees are found entombed in pyroclastic flows and exposed on landscape surfaces providing direct evidence of the nature of Aptian forests in the South Shetland Islands (Falcon-Lang and Cantrill, 2001a). Standing forests of late Albian age are known from Alexander Island (Fig. 1) (Jefferson, 1982; Falcon-Lang and Cantrill, 2000), and wood is common in Late Cretaceous to Paleogene volcanoclastic sequences of the South Shetland Islands (e.g. Poole et al., 2001) and Larsen Basin (e.g. Poole and Francis, 1999, 2000; Poole and
Gottwald, 2001; Poole et al., 2000a,b,c, 2003; Poole, 2002).

Despite the scientific importance of the early discoveries, relatively few taxonomic investigations were made until recently. Wood collected during the Swedish Expedition was described by Gothan (1908), in one of a number of pioneering papers on fossil wood anatomy. In the early 1980 s, there was a resurgence of interest in fossil forests from the Antarctic (e.g. Jefferson, 1982) and the role that they could play in understanding the geologic evolution of the Earth's climate (e.g. Creber and Chaloner, 1984a,b; Francis, 1986). However, scant attention was paid to detailed taxonomic description of this material and there were only a few papers describing the fossil wood anatomy in any detail (e.g. Jefferson and Macdonald, 1981; Lucas and Lacey, 1981; Torres, 1984; Jagmin, 1987). Over the last 15 years, our

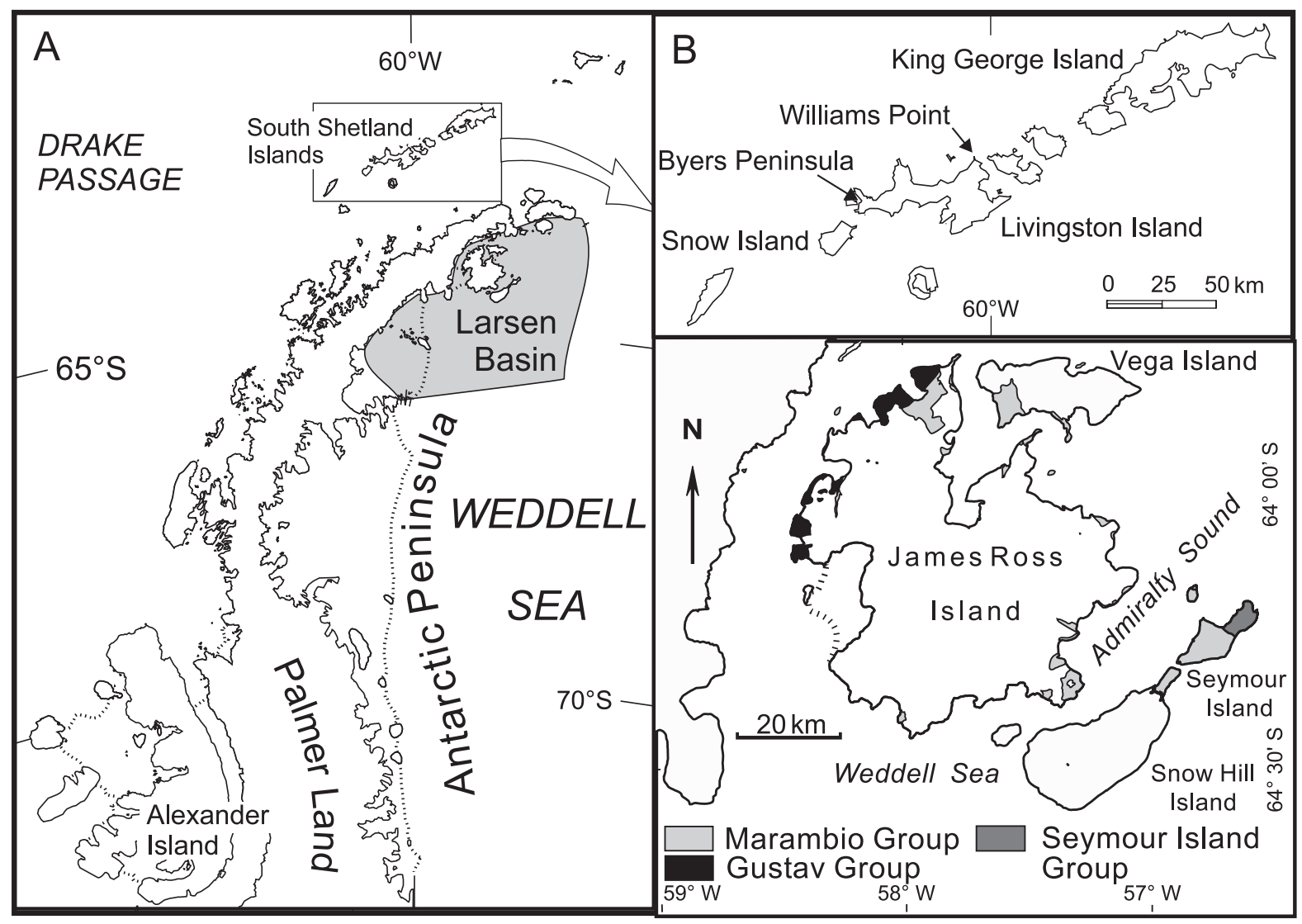

Fig. 1. Locality map showing key regions for fossil plants and geographic names mentioned in the text. 
knowledge of the systematic composition of the Antarctic floras has increased dramatically with well-documented Cretaceous (Torres and Lemoigne, 1989; Chapman and Smellie, 1992; Torres et al., 1997; Falcon-Lang and Cantrill, 2000, 2001a) and Tertiary (Torres and Lemoigne, 1988; Hee and SoonKeun, 1991; Zang and Wang, 1994; Poole et al., 2001) woods being described from the South Shetland Islands and Alexander Island to the west of the Peninsula. Recent taxonomic investigations have also focused on the Cretaceous and Tertiary wood assemblages within the Larsen Basin to the east (Torres et al., 1994; Ottone and Medina, 1998; Poole and Francis, 1999, 2000; Poole and Gottwald, 2001; Poole et al., 2000a,b,c, 2003).

To date, studies on the development of the Antarctic vegetation have concentrated on the palynological and leaf fossil records (e.g. Dettmann and Thomson, 1987; Askin, 1988, 1989, 1990; Hayes, 1999; Hunt, 2001; Hunt and Poole, 2003). These studies have observed similar patterns of change in taxonomic composition and abundance that reflect changes in the vegetation. However, inferences concerning where these changes were taking place in terms of ecological structure were confined to drawing parallels based on comparisons with present-day ecological traits of nearest living relatives. In contrast, fossil wood provides a direct measure of the (relatively local) tree-forming elements within the vegetation, and so provides important constraints with which to compare findings based on the leaf- and (relatively regional) palynological record. The improved state of knowledge of wood assemblages from Antarctica means that it is now timely to synthesize this information into the wider picture of Cretaceous and Tertiary vegetation from these unique high-latitude environments.

\section{Geological setting and palaeoenvironment}

During the Cretaceous to Tertiary, the Antarctic Peninsula formed part of a continental magmatic arc at a convergent plate margin, with palaeo-Pacific oceanic crust being subducted beneath the western margin of the Antarctic Peninsula. The oblique nature of the margin provided the opportunity for the tectonic transport of terranes along the margin (Vaughan and
Storey, 2000). The implication of such tectonic processes is that the floras on the western side of the Antarctic Peninsula could potentially be derived from other geographic regions and thus be exotic (Vaughan and Storey, 2000). This could well be the case for older Mesozoic floras, but major tectonic events at around 100 Ma have been interpreted as representing docking of terranes to the Antarctic Peninsula (Vaughan and Storey, 2000), an event that predates the accumulation of in situ forests such as those from the Late Albian on Alexander Island. Here, fluviatile conditions developed as the last phase of infilling of the Fossil Bluff fore-arc Basin. Sediments were largely sourced from the Antarctic Peninsula to the west but locally uplifted portions of the accretionary prism provided material from the east. Rivers were initially braided as a result of rapid uplift on the Antarctic Peninsula (a consequence of the tectonic events mentioned above) and flashy discharge with highly variable flow conditions are suggested (Nichols and Cantrill, 2002). As basin filling proceeded rivers became more meandering and even more extensive floodplains resulted. Occasional large eruptions gave rise to air fall ash deposits, but these were infrequent.

Cretaceous and Tertiary strata are widespread throughout the Antarctic Peninsula region from Alexander Island in the south to the James Ross region at the northern tip of the Peninsula (Fig. 1). Despite the presence of sedimentary strata spanning the whole Cretaceous to Paleogene interval wood floras are not known from the earliest part of the Cretaceous (Berriasian to Hauterivian), and the earliest part of the Late Cretaceous (Cenomanian to Turonian). Unconformities within the Paleogene preclude the presence of wood from the early part of the Late Palaeocene and Early Eocene. Sedimentary sequences on the Peninsula younger than latest Eocene (earliest Oligocene) are not known to contain wood.

Aptian floras in the South Shetlands Islands represent intra-arc environments and can also be ruled out as representing exotic floras rafted in on terranes. Here, the development of volcanic edifices resulted in extensive volcanoclastic deposition, including pyroclastic flows that entrained trees and overwhelmed a terrain that contained records of plant life. Localized lakes formed, perhaps due to damming of river 
systems, as a result of eruptions. Surrounding the lakes, vegetation redeveloped as indicated by the wellpreserved plant material in these deposits (Cantrill, 2000). This range of environments can be found at a number of spatially and temporally distinct locations from the Late Cretaceous (e.g. Williams Point Beds, Livingston Island) to the Tertiary (e.g. Point Hennequin Formation, South Shetland Islands).

To the east of the Antarctic Peninsula, the Larsen Basin formed in response to continental fragmentation of Gondwana (Hathway, 2000). Cretaceous to Paleogene strata accumulated during thermal subsidence of the basin (Hathway, 2000), with sediment being shed from the Antarctic Peninsula to the west as indicated by palaeocurrent directions and provenance studies (Farquharson, 1982; Ineson, 1989; Pirrie, 1991). Wood is abundant within these marine sequences and is considered to have been derived from the treeforming elements of the vegetation from the Antarctic Peninsula.

\section{Materials and methods}

The material used in this study was collected by the authors from Alexander Island (DJC), Byers Peninsula and Williams Point (DJC, Livingston Island), and Seymour Island (DJC; IP) (Fig. 1). Material was not selectively collected and all individuals were sampled from each locality. This material was supplemented by an extensive wood collection that has accumulated over a 50-year period at the British Antarctic Survey (BAS). The material held at the BAS is the largest collection of Cretaceous and Tertiary fossil wood from Antarctica, with more than 1600 specimens in the collection (Table 1). Furthermore, the material is geographically and stratigraphically well located. Additional material included in this study includes the important collections made by the Swedish South Polar Expedition (1901-1903) now housed in the Swedish Museum of Natural History and supplemented by those on loan from the Polish Academy of Science.

A database was constructed using published records of wood (e.g. Falcon-Lang and Cantrill, 2000, 2001b; Poole and Cantrill, 2001; Poole and Francis, 1999; Poole et al., 2001), and additional material not previously studied or published. These wood specimens were thin-sectioned using standard techniques. Identification of the fossils involved comparisons with wood descriptions (Metcalfe and Chalk, 1950; Metcalfe, 1987; Cutler and Gregory, 1998), wood anatomy atlases (Ilic, 1991), computerised databases for wood identification (e.g. OPCN wood database; Wheeler et al., 1986; Ilic, 1987; LaPasha and Wheeler, 1987) and reference collections

Table 1

Occurrence of Cretaceous and Tertiary wood in the Antarctic Peninsula region

\begin{tabular}{|c|c|c|c|c|c|c|}
\hline Age & $\begin{array}{l}\text { Alexander } \\
\text { Island }\end{array}$ & $\begin{array}{l}\text { Livingston } \\
\text { Island }\end{array}$ & $\begin{array}{l}\text { King George } \\
\text { Island }^{\mathrm{a}}\end{array}$ & $\begin{array}{l}\text { James Ross } \\
\text { and Vega islands }\end{array}$ & $\begin{array}{l}\text { Seymour, Snow Hill } \\
\text { and Cockburn islands }\end{array}$ & Total \\
\hline Eocene & - & - & $35 / 127$ & - & $109 / 111$ & $144 / 238$ \\
\hline Paleocene & $* * \mathrm{~b}$ & - & $? ?$ & - & $94 / 182$ & $94 / 182$ \\
\hline Maastrichtian & $* * \mathrm{~b}$ & - & $* * \mathrm{a}$ & $4 / 28$ & $75 / 87$ & $79 / 87$ \\
\hline Campanian & - & - & $* * \mathrm{a}$ & $22 / 55$ & - & $22 / 55$ \\
\hline Santonian & - & - & - & $7 / 88$ & - & $7 / 88$ \\
\hline Coniacian & - & $84 / 450$ & - & $3 / 41$ & - & $87 / 491$ \\
\hline Turonian & - & - & - & $* *$ & - & - \\
\hline Cenomanian & - & - & - & $* *$ & - & - \\
\hline Albian & $68 / 308$ & - & - & $1 / 1$ & - & $69 / 308$ \\
\hline Aptian & $* *$ & $34 / 83$ & - & $1 / 3$ & - & $35 / 87$ \\
\hline Total & $68 / 308$ & $118 / 533$ & $35 / 127$ & $34 / 178$ & $278 / 380$ & $537 / 1536$ \\
\hline
\end{tabular}

Numbers to the left-hand side indicate specimens examined in this study, including those compiled from published records. Numbers to the right indicates the total number of specimens available for study in the British Antarctic Survey collection. ** Indicates the presence of fossils or strata of that age, but that wood has not been recorded, or examined in this study.

${ }^{a}$ Fossil deposits from King George Island also include nearby islands such as Greenwich Island and Robert Island where Late Cretaceous to Paleogene fossils, including wood has also been recorded.

b Plant fossils of Late Cretaceous or, most probably, Early Tertiary age recorded by Jefferson (1980). 
of extant species housed in the Jodrell Laboratory (Royal Botanic Gardens, Kew) and National Herbarium of the Netherlands (Utrecht University). The sectioned fossil specimens are deposited at the British Antarctic Survey, Cambridge, UK.

All wood was plotted as accurately as possible according to stratigraphic information and relative positions within formations (Fig. 2). The ages of most formations are well constrained, except those in the South Shetland Islands that rely on radiometric dating that has been shown to have some resetting problems. However, although over 500 specimens were utilised in this study, these still represent a relatively sparse stratigraphic coverage (Table 1). The sparse coverage and the broad nature of the synthesis presented here forced us to group the wood at a stage level particularly for the analysis of changes in abundance of wood taxa through time. The abundance of taxa was calculated as a percentage of the total wood identified from each stage in order to allow comparison between stages.

Detailed sampling for finer resolution was made through the Maastrichtian and Paleogene. Here, great care was taken to ensure specimens collected were from one individual piece of wood and not splinters from larger trunks. This ensures that

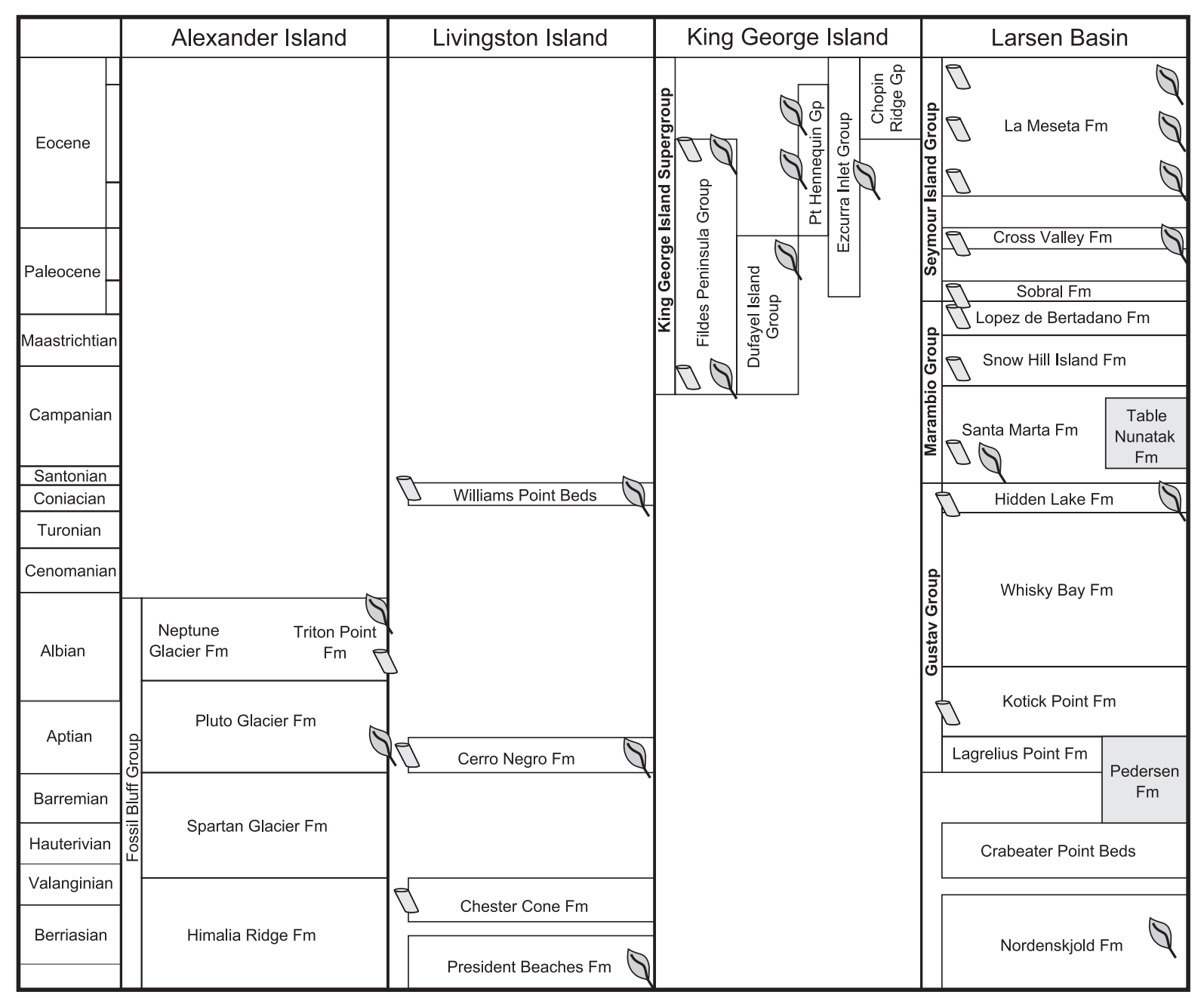

Fig. 2. Stratigraphic distribution of floras in the Antarctic Peninsula region. 
problems relating to collector bias and over representation due to sampling one individual multiple times are not present.

\section{Results and discussion}

The composition of the wood flora reveals four phases of vegetational development in Antarctica during the Aptian to early Tertiary interval. These phases consist of:

(1) Conifer-dominated Aptian and Albian floras. The earliest Cretaceous wood floras are from the Aptian of Livingston Island and the Late Albian of the Alexander Island on the west coast of the Peninsula. These floras are dominated by members of the Podocarpaceae and Araucariaceae with a minor Taxodiaceae/Cupressaceae component.

(2) Conifer-dominated flora with a ?minor angiosperm component. The introduction of angiospermous taxa occurred sometime during the Cenomanian to Turonian but there are, to date, no confirmed wood floras that occurred in this interval. Therefore, this phase cannot be included in the present study.

(3) Angiosperm dominated floras in the Coniacian and Santonian. This phase is marked by abundant angiosperm wood (up to $75 \%$ ) but with high diversity and relatively equal abundance of taxa probably representing true mixed angiosperm forest.

(4) Modernization and radiation of these angiosperm dominated communities. The Campanian and Maastrichtian interval is characterized by the appearance and diversification of, in particular, nothofagaceous woods. Extinctions of many taxa from the preceding intervals occur during the subsequent Paleocene to Eocene interval and angiosperm wood abundance becomes increasingly confined to a few taxa.

\subsection{Taxonomic composition and turnover}

Earlier studies of the palynological and leaf floras from the Antarctic had documented two phases of innovation (Dettmann, 1989; Askin, 1992) with Early
Cretaceous conifer and fern-dominated communities superceded by a mixed conifer-fern-angiosperm flora. The appearance of angiosperms is marked by a suite of early angiosperm pollen grains in the Early Albian such as Clavatipollenites hughesii-a taxon similar to the pollen produced by extant Ascarina (Dettmann, 1989). Angiosperm leaf material also appears in the Albian (Cantrill and Nichols, 1996), many of these are from herbaceous species (e.g. Hydrocotylophyllum). However, some larger leaves are more typical of tree-forming species (e.g. Araliaephyllum, Ficophyllum) (Cantrill and Nichols, 1996). Despite the presence of angiosperm pollen and leaves in the Albian, wood is lacking indicating that these plants were either not common, confined only to specific environments, and/or the early invaders consisted of herbaceous or shrubby taxa (c.f. Dettmann, 1994).

Understanding how rapidly angiosperms migrated into the conifer-fern dominated floras of phase one and subsequently rose to dominance within phase two is confounded by the lack of knowledge of Cenomanian to Turonian floras (Figs. 2 and 3). By phase 3 of the Antarctic ecosystem evolution fossil leaf floras suggest that angiosperms were diverse (Hayes, 1999) and an array of angiosperms had evolved to form a significant tree-forming element of the vegetation during the Coniacian (Chapman and Smellie, 1992; Poole and Cantrill, 2001). The wood flora is relatively diverse in angiospermous groups with the appearance of seven taxa (Fig. 3). Most of these taxa cannot be assigned to modern families but the few wood types that can, are best allied with groups such as Cunoniaceae (Poole et al., 2000b), Monimiaceae (Poole and Gottwald, 2001) and other Laurales (Fig. 3). Few elements of the Coniacian flora survive into the Santonian (five taxa had become extinct by the end of the Coniacian, Fig. 3) where a further four new wood taxa, including the Winteraceae (Poole and Francis, 2000) and Illiciaceae (Poole et al., 2000a), are found and further diversity in Laurales occurs (Poole et al., 2000c) (Fig. 3).

A major change occurs during phase four with the extinction of groups such as Winteroxylon (Winteraceae) and Hedycaryoxylon (Monimiaceae) in the Campanian and further diversification of Laurales (Atherospermoxylon, Sassafrasoxylon), Cunoniaceae (Eucryphiaceoxylon) and other forms (Illicioxylon 


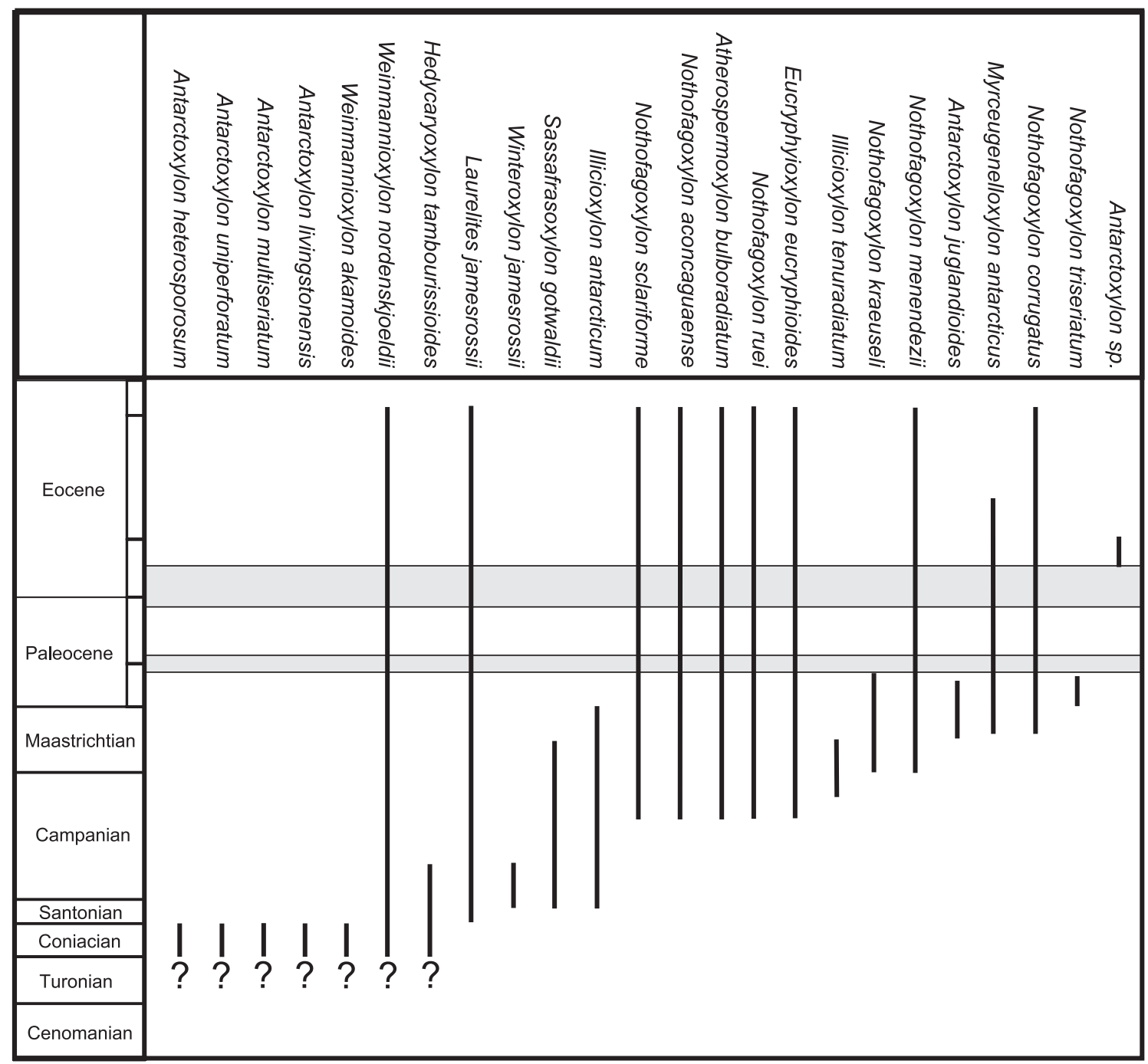

Fig. 3. Stratigraphic range chart for angiosperm wood taxa. Grey zones indicate lack of coverage due to erosion. '?' indicates possible range extensions downward but to date floras of Cenomanian and Turonian ages have not been collected. Taxonomic authorities are given in Poole (2002), Poole and Cantrill (2001), Poole and Francis (1999, 2000), Poole and Gottwald (2001) and Poole et al. (2000a,b,c, 2001, 2003).

tenuradiatum) (Fig. 3). The major taxonomic turnover involves the appearance of Nothofagaceae a characteristic component of modern southern hemisphere floras.

The origins and radiation patterns of the Nothofagaceae have been central to understanding the development of southern hemisphere biogeographic patterns (see Manos, 1997; Swenson et al., 2000, 2001). The phylogenetically informative characters of Nothofagaceae pollen, coupled with its excellent fossil record has provided a powerful tool to evaluate familial phylogenetic hypotheses based predominantly on molecular and morphological data. However, the pollen record for the early part of the evolutionary history has proved problematic. Pollen characters suggest the presence of ancestral groups and the timing of the appearance of the four modern sections within Nothofagus is still unresolved with all four sections having a Late Campanian appearance. Until recently, the nothofagaceous wood record has been neglected in such studies largely due to the plethora of poorly circumscribed names. However, a 
recent revision by Poole (2002) has resolved these nomenclatural issues. Although wood characters to date have not been integrated within a phylogenetic framework, strong comparisons can be made with extant species and these provide a basis for assigning the wood to sections (Poole, 2002). The Campanian to Maastrichtian stage is marked by angiosperm radiation that involves, in particular, Nothofagoxylon species. The wood record suggests the appearance of sections Lophozonia (N. ruei, $N$. aconcaguaense) and Nothofagus ( $N$. sclariforme) in the Campanian (Fig. 3) prior to the appearance of Fuscospora (N. corrugatus) in the Maastrichtian (Poole, 2002). Interestingly, wood from section Brassospora has not yet been recognized in Antarctic sediments despite its presence in the pollen record. The lack of wood and the depauperate leaf record suggest that Brassospora is over represented in the pollen record due to its propensity to produce copious pollen (Paul and Hill, 2003). In the Campanian, the diversification of wood taxa involves the appearance of six new taxa (three of which are Nothofagoxylon) and two extinctions. In the Maastrichtian, a further six new taxa (four of which are Nothofagoxylon) appear but the extinction rates of other angiospermous taxa (e.g. Sassafrasoxylon, Illicioxylon antarcticum) also increase (i.e. four taxa) and new (non-nothofagaceous) taxa are usually encountered infrequently (e.g. Myceugenelloxylon) (Fig. 3).

\subsection{Broad-scale changes in abundance of wood taxa}

The patterns seen in taxonomic turnover which form the basis of the four phase evolution of Antarctic forest ecology is reinforced by changes in abundance of wood taxa (Figs. 4 and 5). Abundance data is interpreted to reflect the importance of that taxonomic group within the vegetation. However, abundance data can be strongly influenced by other variables. For example, pollen abundance is strongly influenced by the biology of the organism, wind-pollinated plants produce copious pollen and so are over represented with respect to their importance in the source vegetation. Similar problems exist for wood where large trunks are considered the same as small branches and so trees with a more spreading and branched habit may be over represented in the abundance data relative to their importance in the source vegetation. This may be compounded by preservation. We have tried to minimize this type of bias by ensuring all counted specimens were larger branches and where specimens were strongly shattered that they were counted as one individual and this was confirmed through examination of thin sections. The majority of specimens examined in this study are from branches or trunks and despite the inherent biases probably broadly reflect the importance of groups within the source vegetation.

Within the conifers Podocarpoxylon wood is particularly abundant (60-85\%) during phase one from the Aptian to Campanian. Although this wood type persists through into the Tertiary, it decreases markedly in abundance (to 23-35\%) during the Campanian to Eocene (Fig. 4). Changes in the forest structure and canopy are reflected in the post Santonian replacement of the tree-forming Podocarpoxylon wood by the plant producing the Phyllocladoxylon type (Fig. 4). This wood type is absent in the Aptian to Santonian interval and only appears in the Campanian rising quickly to c. $11 \%$. By the Eocene, it has become the dominant conifer representing $58 \%$ of the abundance. The pollen record also supports these changes as Early Cretaceous forms such as Podocarpidites and Microcachyridites decrease in abundance with an associated dramatic increase in the Phyllocladidites and Dacrycarpites forms attesting to major changes in the composition of the podocarp canopy. Abundance data on Podocarpaceae indicates that these plants are the main forest-forming element in the vegetation.

Araucarian abundance remains fairly constant at 25-30\% during the Early Cretaceous, but begins to decrease during the mid-Cretaceous (Albian-Coniancian) and dramatically decreases in the Eocene where it contributes only about $6.5 \%$ of the total abundance (Fig. 4). The Aptian and Paleocene intervals are richest in araucarians and this corresponds to sequences that are relatively richer in proximal volcanic deposits suggesting a strong ecological association. However, this pattern does not occur in the volcanicrich sequences on King George Island, which might reflect the small sample size from a limited geographic area. Wood ascribed to taxodiaceous and cupressaceous conifers, although locally abundant (e.g. Collins Glacier Flora; Poole et al., 2001), 


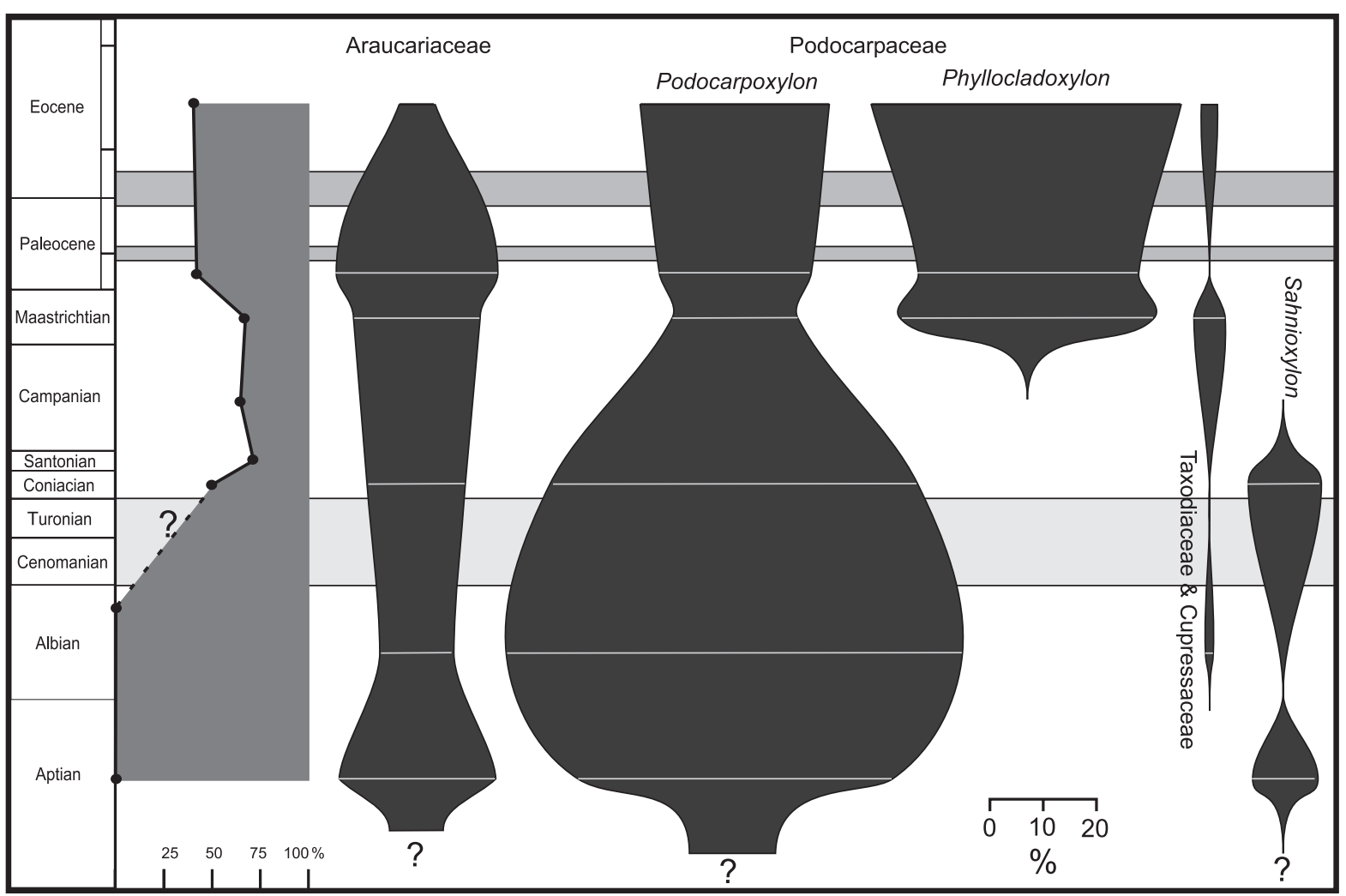

Fig. 4. Abundance of conifer wood genera as a total percentage of conifer wood specimens identified. Graph on left indicates relative abundance of conifer wood (shaded) relative to angiosperms. Balloon diagrams are plotted as a mid point for each geological stage where data exists (thin line). Dark grey horizontal shading indicates non-deposition, light grey shading indicates sediments exist but floras have not been sampled. Width of the balloon represents percentage value normalized against total number of specimens for that stratigraphic interval. Generic circumspection follows Bamford and Philippe (2001). Araucariaceae encompasses wood taxa placed in Araucarioxylon, Araucaiopitys and Agathoxylon by previous workers. Taxodiaceae and Cupressaceae wood is represented by the form genera Taxodioxylon and Cupressinoxylon.

generally contribute only a minor component of the conifer abundance during all phases.

Within the angiosperms, broad changes in abundance complement the turnover patterns outlined above (Fig. 5). During phase 1, angiosperm wood is lacking from Aptian and Albian strata. The initial invasion of the angiosperms during the Cenomanian to Turonian (phase 2) and into the Coniacian interval largely involved Antarctoxylon - an array of wood types from predominantly large diameter organs that represent branches from trees or trunk wood (Fig. 5). Unfortunately as these wood types cannot be related to the extant families, it is difficult to ascertain the familial diversity present within the canopy. The few forms that can be identified represent members of the Laurales and Cunoniales; these represent about 28\% of the angiosperm wood specimens recovered. At a specific level, there is relatively uniform abundance between taxa suggesting a truly mixed canopy (Fig. 5). Radiation into the canopy was rapid such that by the Coniacian over half the wood samples recovered are angiospermous. This pattern is better documented in the Santonian where angiosperm abundance has increased to $70 \%$ (Fig. 5). Although most of the Antarctoxylon species have been replaced, abundance between the various genera is relatively uniform with all taxa ranging between $12 \%$ and $25 \%$ of the total angiosperm abundance (Fig. 5). At a family level, the canopy is dominated by Lauraceae and Cunoniaceae with Illiciaceae and Winteraceae of lesser importance. This relative uniform mix of species supports a concept of a diverse mixed canopy. As conifers 


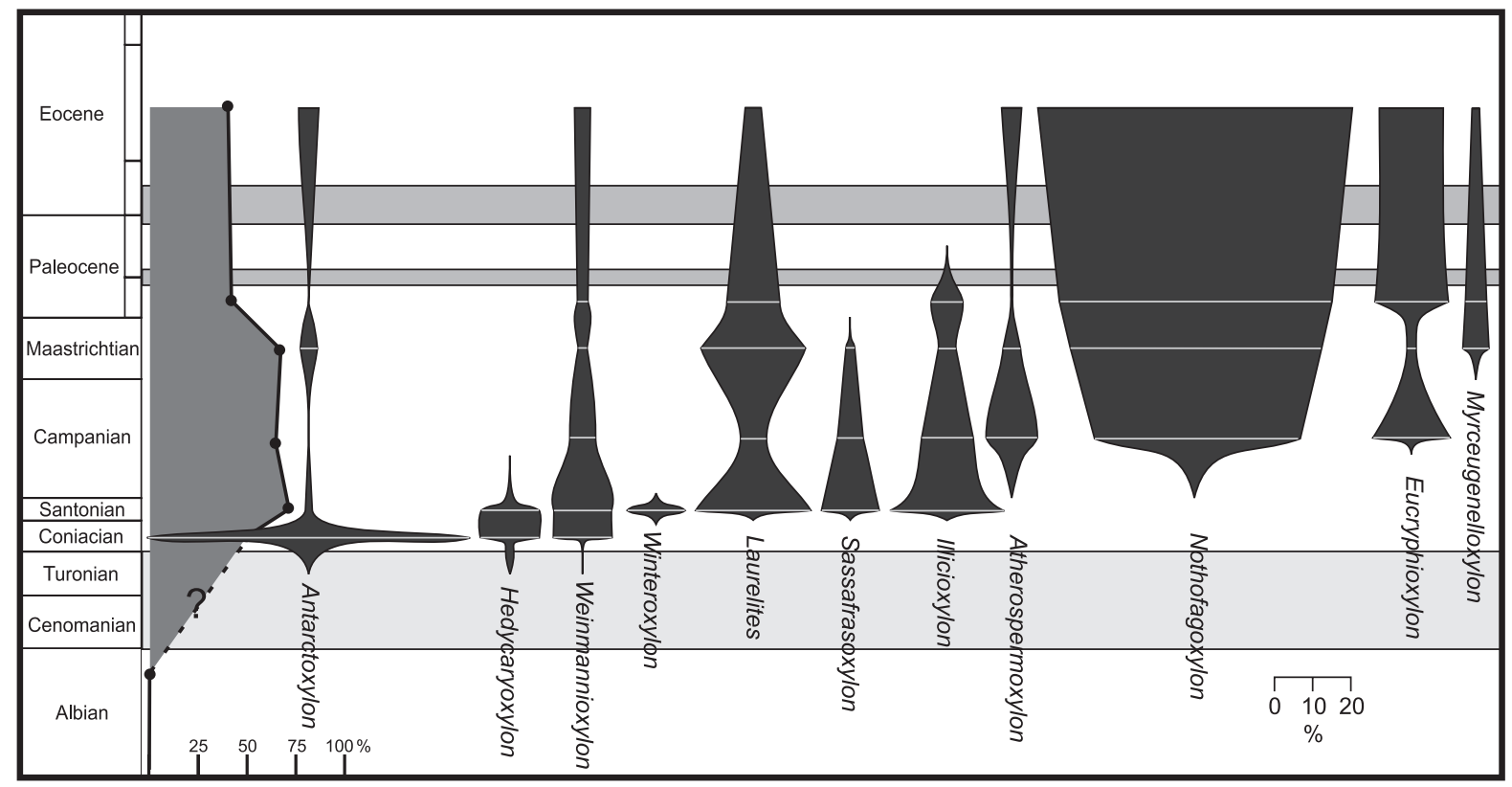

Fig. 5. Abundance of angiosperm wood genera as a total percentage of angiosperm wood specimens identified. Shaded portion of graph on left indicates relative abundance of angiosperm wood relative to conifers. Balloon diagrams and shading the same as in Fig. 4. Width of the balloon represents percentage value normalized against total number of specimens for that stratigraphic interval. Generic circumspection follows that given in Poole (2002), Poole and Cantrill (2001), Poole and Francis (1999, 2000), Poole and Gottwald (2001) and Poole et al. (2000a,b,c, 2001, 2003).

decrease in importance the angiosperms reach a peak of abundance in the Santonian and account for nearly three-quarters of the wood encountered (Fig. 5).

Following this peak of abundance, angiosperm wood begins to decline gradually to the Campanian where it contributes $63 \%$ of the abundance with each angiosperm taxon remaining fairly uniform during the Coniacian to Campanian suggesting that they are all equally important in the vegetation. Following the appearance of Nothofagoxylon in the Campanian, many other angiospermous taxa decline.

Major taxic turnover in the Campanian is marked by changes in patterns of abundance that continue through the Maastrichtian and into the Tertiary. Conifer-angiosperm ratios remain fairly uniform throughout the Campanian and early Maastrichtian with members of the Laurales and Cunoniaceae continuing to be important members of the canopy. Nothofagaceae wood appears in this interval and it rapidly increases in abundance so that nearly half (44\%) of the angiosperm wood in the Campanian belongs to the Nothofagaceae. This rapid rise to ecological dominance indicates major changes to the forest structure with the canopy increasingly becoming dominated by a few taxa of which the most important is Nothofagaceae. By the Maastrichtian, the abundance of total angiosperms was $65 \%$ but rapidly declined into the Palaeocene and Eocene (40\%). At the same time, the abundance of Nothofagus wood increases indicating replacement of the non-Nothofagus canopy by conifers although groups such as the Cunoniaceae remain a small but important compo-

Fig. 6. Detailed wood distribution through the upper part of the Lopez de Bertadano and lower Sobral formations on Seymour Island. Summary lithostratigraphic section with a plot of wood abundance calculated as a total percentage of wood sampled from the succession. Note the sudden influx of wood at key levels (labelled 1-3) and gradual decline in wood abundance over the next few tens of metres. (A-C) Detailed logs of wood-rich intervals illustrating the increase in importance of conifer wood (black line) through each cycle of wood influx (dashed line). Percentage wood is calculated as moving average using a $10-\mathrm{m}$ stratigraphic interval. The initial influx of wood is largely dominated by angiosperm wood. Section logs and dates after Crame et al. (2004). 


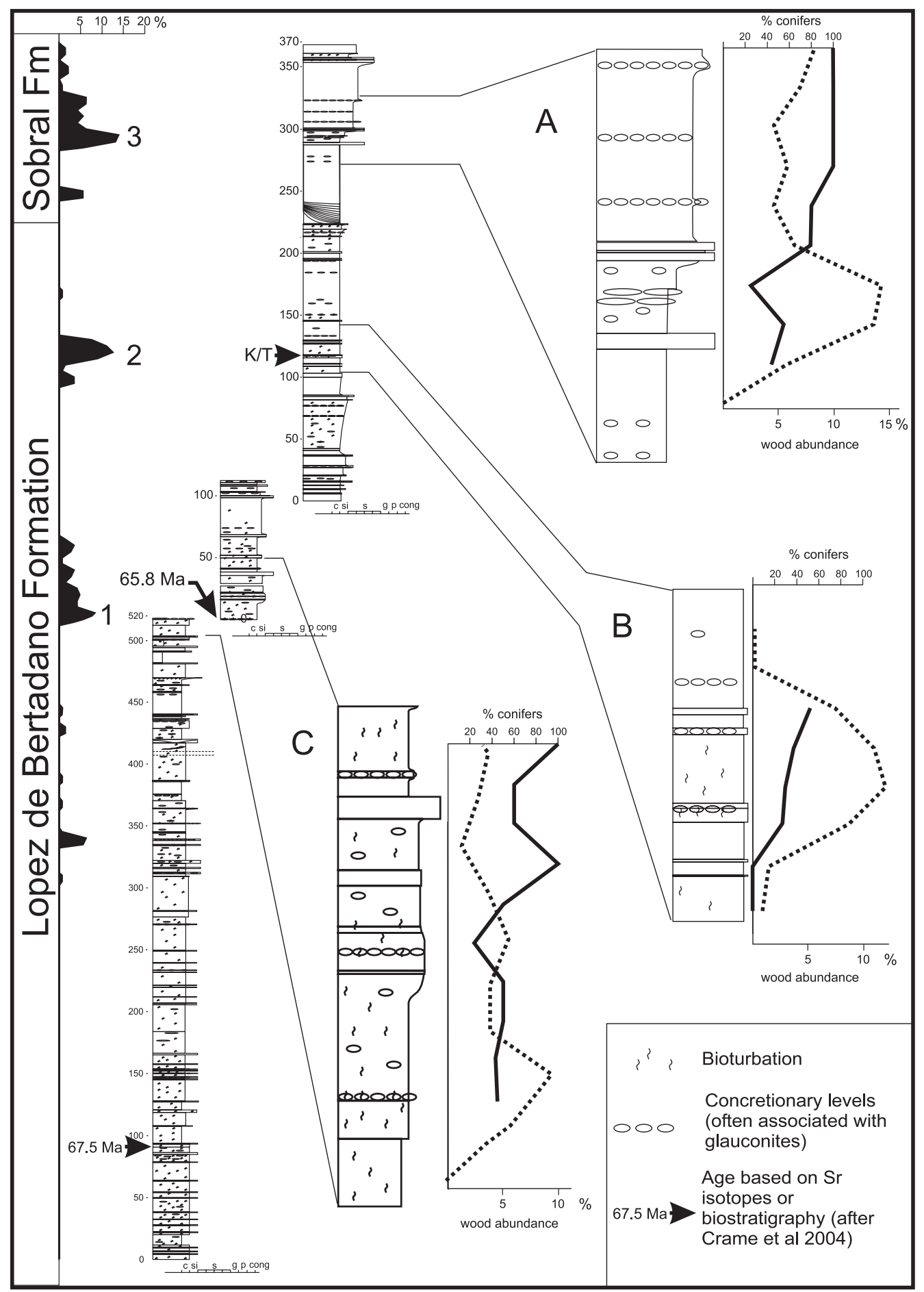


nent. This pattern continues into the Eocene and reinforces the change from a mixed canopy to one dominated by Nothofagaceae.

The rise to importance of Nothofagaceae is not static within the family with different sections being important at different times. The initial rise of Nothofagaceae within the Campanian occurs mainly within section Nothofagus with $67 \%$ of the Nothofagaceae specimens belonging to this group. In contrast, Nothofagus section Lophozonia remains static during the Late Cretaceous before reaching its acme in the Paleocene (85\%) and undergoing a subsequent decline in the Eocene $(41 \%)$ along with section Nothofagus (37\%) when Fuscospora becomes more abundant $(23 \%)$.

\subsection{Vertical variation in abundance of taxa}

Abundance data also indicates small-scale changes both between geographic regions and through narrow stratigraphic intervals. This is important for understanding the occurrence and abundance data in terms of the vegetation from which it was derived. The upper part of the Lopez de Bertadano Formation and the overlying Sobral Formation on Seymour Island contains an abundant record of wood (Table 1), largely as a result of concentrated collecting efforts. Late Maastrichtian to early Palaeogene units accumulated in an open marine setting within a generally coarsening upwards sequence reflecting basin-shallowing events (Fig. 6). Each cycle of sedimentation is marked by a disconformable to slightly unconformable surface capped by a lag rich in glauconite, marine shells, vertebrate remains and fossil wood (Fig. 6). The three main peaks in wood abundance are seen through the section (Fig. 6), and each has slightly different characteristics. In each successive peak (Fig. 6 , labelled 1-3), the conifers become relatively more common and this seems to correspond to an increase in detrital volcanic material and reworked air fall tuffaceous deposits. This suggests a link between vegetation composition and volcanic activity. Similar shifts in taxonomic composition and abundance can be seen in local vertical successions. For example, the Aptian Cerro Negro Formation on Byers Peninsula and Snow Island developed on pre-existing landscape with topographic relief (Hathway, 1997). This landscape has soil surfaces and tree material that indicates araucarian- and podocarp-dominated communities. The development of a volcanic edifice (Hathway, 1997) results in a shift in wood composition to communities richer in podocarps and other gymnosperms such as Sahnioxylon (Falcon-Lang and Cantrill, 2001c).

Each peak concentration of wood is also characterized by a number of features (Fig. 6A-C). Fossil wood is initially abundant, but decreases in importance up section until beds are largely barren (Fig. 6). Interestingly, each cycle shows the same pattern of taxonomic abundance. Basally wood material is dominated by angiosperms but up section the proportion of conifers increases (Fig. 6A-C). The sedimentological setting suggests these wood-rich zones cap a transgressive surface and represent coastal plain vegetation that has been eroded into the basin. The shift to more conifer-rich floras reflects an increasing input from highland regions. Therefore, the changes in wood composition reflect spatial heterogeneity in the vegetation with the coastal plain forests being more angiosperm rich than the highland regions.

\subsection{Geographical variation in wood flora composition}

The geographical spread of floras from the east side of the Antarctic Peninsula to the west side, along with the different palaeoenvironments (e.g. fore arc coastal plain, intra-arc volcanic environments, backarc plain), provides the opportunity to examine the spatial pattern of distribution. Pairwise comparisons between coeval floras reveal important differences in taxonomic composition. Sahnioxylon an extinct gymnosperm taxon is only known from the west side of the Antarctic Peninsula (Falcon-Lang and Cantrill, 2001c; Poole and Cantrill, 2001). Furthermore, although it is confined to intra-arc environments in the Aptian (Falcon-Lang and Cantrill, 2001c) and Coniacian (Poole and Cantrill, 2001), it is missing from Albian floras from the fore arc coastal plain.

Compositional differences can also be seen between the Eocene floras to the west of the Antarctic Peninsula in the South Shetland Islands (King George Island) and Seymour Island floras to the east. Those floras to the west of the Peninsula are relatively depauperate in conifer material, with up to only $25 \%$ of total abundance, represented by a low but 
significant podocarpaceous and cupressaceous element in both the wood and leaf floras (Poole et al., 2001). No evidence for the Araucariaceae was recorded in these Eocene wood floras to the west of the Peninsula examined for abundance counts even though wood has been described (Lucas and Lacey, 1981; Torres and Lemoigne, 1988) and foliage and reproductive material has been recorded (Hunt, 2001; Hunt and Poole, 2003). In contrast, coeval wood assemblages east of the Antarctic Peninsula on Seymour Island (La Meseta Formation) contain relatively more conifers (up to $40 \%$ by abundance). The conifer element is also rich in Podocarpaceae (Phyllocladoxylon, Podocarpoxylon) but with subsidiary Araucariaceae and rare Cupressaceae (Torres et al., 1994).

Angiosperm floras on the west of the Peninsula have a high percentage of Nothofagoxylon (c. 50\%), particularly of the section Fuscospora (e.g. N. corrugatus) alongside an important cunoniaceous element. On the east side of the Peninsula within the angiosperms, Nothofagoxylon is relatively more abundant $70 \%$ with a number of other taxa (such as Laurelites jamesrossii) not found in coeval floras to the west.

This east-west difference is perhaps not surprising when we consider the distribution of taxa in the closest analogues to these fossil floras, growing in Patagonia today. Prevailing moist westerly winds and the Andean mountain chain result in a steep precipitation gradient and temporal differences in distribution from west to east even though annual rainfall is essentially the same (Ohga, 1987). Furthermore, volcanic disturbance processes are more common within the Andean chain than to the east so resulting in different vegetation dynamics. These two factors are particularly important when considering the compositional differences between floras from the east of the Antarctic Peninsula with those of the volcanic dominated palaeoenvironments of the South Shetland Islands. It may well be that the differences seen in composition of the fossil floras reflect similar environmental gradients and support the notion of a spatial heterogeneous mix of forest types through the Cretaceous and Tertiary similar to that seen today in a transect from the narrow western coastal plains through the coastal ranges to the high Andes and eastward into the coast.

\section{Conclusions}

The wood flora provides a direct snapshot of treeforming elements within the Antarctic vegetation such that this record provides an important source of information pertaining to floristic evolution and vegetational makeup. The results from these studies complement and supplement hypotheses put forward based on leaf and palynological studies. Comparison of information based solely on wood with the leaf and spore/pollen record allows important inferences about the structure and dynamics of plant communities. This analysis of over 500 fossil woods from the Cretaceous and Tertiary of Antarctica has revealed broad-scale compositional changes associated with the radiation of angiosperms into the Antarctic region. The shift from shrubby elements, to ones dominating the canopy in the early phase of invasion, and the modernization of floras during the Campanian and Maastrichtian are particularly important. Changes in abundance reinforce these patterns, particularly the rise in Nothofagus wood through the latest Cretaceous and Paleogene. Comparisons between coeval floras from different geographic regions reveal subtle interplays between tectonics and palaeoenvironments. The contrasts between east coast and west coast floras may signify contrasts in climate patterns and volcanic disturbance processes as predicted from an examination of environmental conditions (climate and land form processes) in the Andes today. Small-scale temporal succession points to an important role of local sea level change in controlling the abundance and composition of vegetation, probably largely due to the amount of coastal plain available for colonization.

\section{References}

Askin, R.A., 1988. Campanian to Paleocene palynological succession of Seymour Island and adjacent islands, northeastern Antarctic Peninsula. In: Feldmann, R.M., Woodburne, M.O. (Eds.), Geology and Paleontology of Seymour Island, Antarctica Peninsula, Memoir - Geological Society of America, vol. 169, pp. $131-153$.

Askin, R.A., 1989. Endemism and heterochroneity in the Late Cretaceous (Campanian) to Paleocene palynofloras of Seymour Island, Antarctica: implications for origins, dispersal and palaeoclimates of southern floras. In: Crame, J.A. (Ed.), Origins and Evolution of the Antarctic Biota, Special Publication - Geological Society of London, vol. 47, pp. 107-119. 
Askin, R.A., 1990. Campanian to Paleocene spore and pollen assemblages from the upper Campanian and Mastrichtian of Seymour Island. Review of Palaeobotany and Palynology 65, $105-113$.

Askin, R.A., 1992. Late Cretaceous-early Tertiary Antarctic outcrop evidence for past vegetation and climates. In: Kennett, J.P., Warnke, D.A. (Eds.), The Antarctic Palaeoenvironment: A Perspective on Global Change, vol. 56. Antarctic Research Series American Geophysical Union, Washington, pp. 61-73.

Bamford, M., Philippe, M., 2001. Jurassic-Early Cretaceous gondwanan homoxylous woods: a nomenclatural revision of the genera with taxonomic notes. Review of Palaeobotany and Palynology 113, 287-297.

Cantrill, D.J., 2000. A Cretaceous macroflora from a freshwater lake deposit, President Head Snow Island Antarctica. Palaeontographica Abteilung B Palaeophytologie 253, 153-191.

Cantrill, D.J., Nichols, G.J., 1996. Taxonomy and palaeoecology of Early Cretaceous (Late Albian) angiosperm leaves from Alexander Island, Antarctica. Review of Palaeobotany and Palynology 92, 1-28.

Chapman, J.L., Smellie, J.L., 1992. Cretaceous fossil wood and palynomorphs from Williams Point, Livingston Island, Antarctic Peninsula. Review of Palaeobotany and Palynology 74, 163-192.

Crame, J.A., Francis, J.E., Cantrill, D.J., Pirrie, D., 2004. Maastrichtian stratigraphy of Antarctica. Cretaceous Research 25, 411-423.

Creber, G.T., Chaloner, W.G., 1984a. Influence of environmental factors on the wood structure of living and fossil trees. The Botanical Review 50, 357-448.

Creber, G.T., Chaloner, W.G., 1984b. Climatic indications from growth rings in fossil woods. In: Brenchley, P. (Ed.), Fossils and Climate. John Wiley \& Sons, pp. 49-74.

Cutler, D.F., Gregory, M., 1998. Anatomy of the Dicotyledons: Volume IV. Saxifragales. Clarendon Press, Oxford.

Dettmann, M.E., 1989. Antarctica: Cretaceous cradle of austral temperate rainforests? In: Crame, J.A. (Ed.), Origins and Evolution of Antarctic Biota, Special Publication - Geological Society of London, vol. 47, pp. 89-105.

Dettmann, M.E., 1994. Cretaceous vegetation: the microfossil record. In: Hill, R.S. (Ed.), History of the Australian Vegetation: Cretaceous to Recent. Cambridge University Press, Cambridge, pp. 143-170.

Dettmann, M.E., Thomson, M.R.A., 1987. Cretaceous palynomorphs from the James Ross Island area, Antarctica-a pilot study. Bulletin - British Antarctic Survey 77, 13-59.

Eight, J., 1833. Description of new crustaceous animal found on the shores of South Shetland Islands, with remarks on their natural history. Transcriptions of the Albany Institute 2, 53-69.

Falcon-Lang, H.J., Cantrill, D.J., 2000. Cretaceous (Late Albian) coniferales of Alexander Island, Antarctica. 1: wood taxonomy: a quantitative approach. Review of Palaeobotany and Palynology $111,1-17$.

Falcon-Lang, H.J., Cantrill, D.J., 2001a. Biodiversity and terrestrial ecology of a mid-Cretaceous, high latitude floodplain, Alexander Island, Antarctica. Journal of the Geological Society (London) 158, 709-724.

Falcon-Lang, H.J., Cantrill, D.J., 2001b. Leaf phenology of some mid-Cretaceous polar forests, Alexander Island, Antarctica. Geological Magazine 138, 39-52.
Falcon-Lang, H.J., Cantrill, D.J., 2001c. Gymnosperm woods from the Cretaceous (mid-Aptian) Cerro Negro Formation, Byers Peninsula, Livingston Island, Antarctica: the arborescent vegetation of a volcanic arc. Cretaceous Research 22, 277-293.

Farquharson, G.W., 1982. Late Mesozoic sedimentation in the northern Antarctic Peninsula and its relationship to the southern Andes. Journal of the Geological Society (London) 139, $721-727$.

Francis, J.E., 1986. Growth rings in Cretaceous and Tertiary wood from Antarctica and their palaeoclimatic implications. Palaeontology 29, 665-684.

Gothan, W., 1908. Die fossilen Holzer von der Seymour und Snow Hill-Insel. Wissenschaftliche ergebnisse Der Schwedischen Sudpolar-Expedition 1901-1903 3 (8), 1-33.

Hathway, B., 1997. Nonmarine sedimentation in an Early Cretaceous extensional continental-margin arc, Byers Peninsula, Livingston Island, South Shetland Islands. Journal of Sedimentary Research 67, 686-697.

Hathway, B., 2000. Continental rift to back-arc basin: JurassicCretaceous stratigraphical and structural evolution of the Larsen Basin, Antarctic Peninsula. Journal of the Geological Society (London) 157, 417-432.

Hayes, P.A., 1999. Cretaceous angiosperm floras from Antarctica. $\mathrm{PhD}$ thesis, University of Leeds, Leeds, UK.

Hee, Y.C., Soon-Keun, C., 1991. Studies on the gymnospermous fossil woods from the King George Island. Journal of Sedimentary Research 2 (1), 179-185.

Hunt, R.H., 2001. Biodiversity and palaeoecology of Tertiary fossil floras in Antarctica. PhD thesis, University of Leeds, Leeds, UK.

Hunt, R.H., Poole, I., 2003. Revising Paleogene West Antarctic climate and vegetation history in light of new data from King George Island. In: Wing, S.L., Gingerich, P.D., Schmitz, B., Thomas, E. (Eds.), Causes and Consequences of Globally Warm Climates in the Early Paleogene, Special Paper - Geological Society of America, vol. 369, pp. 395-412.

Ilic, J., 1987. The CSIRO Family Key for Hardwood Identification. E.J. Brill, Leiden.

Ilic, J., 1991. CSIRO Atlas of Hardwoods. Crawford House Press and CSIRO Publications, Australia.

Ineson, J.R., 1989. Coarse-grained submarine fan and slope apron deposits in a Cretaceous back-arc basin, Antarctica. Sedimentology 36, 793-819.

Jagmin, N.I.B., 1987. Estudo anatômico dos troncos fósseis de Admirality Bay, King George Island (Peninsula Antárctica). Acta Biologica Leopoldensia 9, 81-98.

Jefferson, T.H., 1980. Angiosperm fossils in supposed Jurassic volcanogenic shales, Antarctica. Nature 285, 157-158.

Jefferson, T.H., 1982. Fossil forests from the Lower Cretaceous of Alexander Island, Antarctica. Palaeontology 25, 681-708.

Jefferson, T.H., Macdonald, D.I.M., 1981. Fossil wood from South Georgia. Bulletin - British Antarctic Survey 54, 57-64.

LaPasha, C.A., Wheeler, E.A., 1987. A microcomputer based system for computer-aided wood identification. International Association of Wood Anatomists Bulletin 8, 347-354.

Larsen, C.A., 1894. The voyage of the "Jason" to the Antarctic regions. Geographical Journal 4, 333-344. 
Lucas, R.C., Lacey, W.S., 1981. A permineralized wood flora of probable Early Tertiary age from King George Island, South Shetland Islands. Bulletin - British Antarctic Survey 53, $147-151$.

Manos, P.S., 1997. Systematics of Nothofagus (Nothofagaceae) based on rDNA spacer sequences (ITS): taxonomic congruence with morphology and plastid sequences. American Journal of Botany 84, 1137-1155.

Metcalfe, C.R., 1987. Anatomy of the dicotyledons, Second edition. Magnoliales, Illiciales and Laurales, vol. 3. Clarendon Press, Oxford.

Metcalfe, C.R., Chalk, L., 1950. Anatomy of the Dicotyledons. Vols. 1 and 2. Clarendon Press, Oxford.

Nichols, G.J., Cantrill, D.J., 2002. Tectonic and climatic controls on a Mesozoic forearc basin succession, Alexander Island, Antarctica. Geological Magazine 139, 313-330.

Ohga, N., 1987. The plant ecology of the cloud forests of the eastern and western slopes of the Andes I. In: Nishida, M. (Ed.), Microclimatic conditions of the forests of Bolivia and Chile, Contributions to the botany of the Andes, vol. II. Academia Scientific Book, Tokyo, pp. 12-22.

Ottone, E.G., Medina, F.A., 1998. A wood from the Early Cretaceous of James Ross Island. Ameghiniana 35, 291-298.

Paul, R., Hill, R.S., 2003. Nothofagus kiandrensis (Nothofagaceae subgenus Brassospora), a new macrofossil leaf species from Miocene sediments at Kiandra, New South Wales. Australian Systematic Botany 16, 549-559.

Pirrie, D., 1991. Controls on the petrographic evolution of an active margin sedimentary sequence: the Larsen Basin, Antarctica. In: Morton, A.C., Todd, S.P., Haughton, P.D.W. (Eds.), Developments in Sedimentary Provenance Studies, Special Publication Geological Society of London, vol. 57, pp. 231-249.

Poole, I., 2002. Systematics of Cretaceous and Tertiary Nothofagoxylon: implications for Southern Hemisphere biogeography and evolution of the Nothofagaceae. Australian Systematic Botany 15, 247-276.

Poole, I., Cantrill, D.J., 2001. Fossil woods from Williams Point Beds, Livingston Island, Antarctica: a Late Cretaceous southern high latitude flora. Palaeontology 44, 1081-1112.

Poole, I., Francis, J.E., 1999. The first record of fossil atherospermataceous wood from the Upper Cretaceous of Antarctica. Review of Palaeobotany and Palynology 107, 97-107.

Poole, I., Francis, J.E., 2000. The first record of fossil wood of Winteraceae from the Upper Cretaceous of Antarctica. Annals of Botany 85, 307-315.

Poole, I., Gottwald, H., 2001. Monimiaceae sensu lato, an element of Gondwanan polar forests: evidence from the Late Cretaceous-early Tertiary wood flora of Antarctica. Australian Systematic Botany 14, 207-230.

Poole, I., Gottwald, H., Francis, J.E., 2000a. Illiciaceae, an element of Gondwanan polar forests? Late Cretaceous and Early Tertiary woods of Antarctica. Annals of Botany 86, 421-432.

Poole, I., Cantrill, D.J., Hayes, P., Francis, J.E., 2000b. The fossil record of Cunoniaceae: new evidence from Late Cretaceous wood of Antarctica. Review of Palaeobotany and Palynology $111,127-144$.
Poole, I., Richter, H., Francis, J.E., 2000c. Gondwana origins for Sassafras (Lauraceae)? Evidence from Late Cretaceous fossil wood of Antarctica. International Association of Wood Anatomists Journal 21, 463-475.

Poole, I., Hunt, R.H., Cantrill, D.J., 2001. A fossil wood flora from King George Island: ecological implications for Antarctic Eocene vegetation. Annals of Botany 88, 33-54.

Poole, I., Mennega, A.M.W., Cantrill, D.J., 2003. Valdivian ecosystems in the late cretaceous and early Tertiary of Antarctica as evidenced from fossil wood. Review of Palaeobotany and Palynology 124, 9-27.

Sharman, G., Newton, E.T., 1894. Notes on some fossils from Seymour Island, in the Antarctic regions, obtained by Dr. Donald. Transactions of the Royal Society of Edinburgh 37, $707-709$.

Sharman, G., Newton, E.T., 1898. Notes on some additional fossils collected at Seymour Island, Graham's Land, by Dr. Donald and Captain Larsen. Proceedings of the Royal Society of Edinburgh $22,58-61$.

Swenson, U., Hill, R.S., McLoughlin, S., 2000. Ancestral area analysis of Nothofagus (Nothofagaceae) and its congruence with the fossil record. Australian Systematic Botany 13, 469-478.

Swenson, U., Backlund, A., McLoughlin, S., Hill, R.S., 2001. Nothofagus biogeography revisited with special emphasis on the enigmatic distribution of subgenus Brassospora in New Caledonia. Cladistics 17, 28-47.

Torres, T., 1984. Nothofagoxylon antarcticus n. sp., Madera fósil del Terciario de la isla Rey Jorge, isles Shetland del Sur, Antártica. Serie Científica - Instituto Antártico Chileno 31, 39-52.

Torres, T., Lemoigne, Y., 1988. Maderas fósiles terciarias de la Formación Caleta Arctowski, Isla Rey Jorge, Antártica. Serie Científica - Instituto Antártico Chileno 37, 69-107.

Torres, T., Lemoigne, Y., 1989. Hallazagos de maderas fósiles de Angiospermas y Gimnospermas del Cretácico Superior en punta Williams, isla Livingston, islas Shetland del Sur, Antárctica. Serie Científica - Instituto Antártico Chileno 39, 9-29.

Torres, T., Marenssi, S., Santillana, S., 1994. Maderas fósiles terciarias de la Formación Caleta Arctowski, Isla Rey Jorge, Antártica. Serie Científica - Instituto Antártico Chileno 44, 17-38.

Torres, T., Barale, G., Méon, H., Philippe, M., Thévenard, F., 1997. Cretaceous floras from Snow Island (South Shetland Islands, Antarctica) and their biostratigraphic significance. In: Ricci, C.A. (Ed.), The Antarctic Region: Geological Evolution and Processes. Terra Antarctica Publication, Siena, pp. 1023-1028.

Vaughan, A.P.M., Storey, B.C., 2000. The eastern Palmer Land shear zone: a new terrane accretion model for the Mesozoic development of the Antarctic Peninsula. Journal of the Geological Society (London) 157, 1243-1256.

Wheeler, E.A., Pearson, R.G., LaPasha, C.A., Zack, T., Hatley, W., 1986. Computer-aided wood identification. Bulletin - North Carolina. Agricultural Research Service 474, 1-160.

Zang, S., Wang, Q., 1994. Paleocene petrified wood on the west side of Collins Glacier in the King George Island, Antarctica. In: Yanbin, S. (Ed.), Stratigraphy and Palaeontology of Fildes Peninsula King George Island, Antarctica, State Antarctic Committee Monograph, vol. 3. Science Press, pp. 231-238. 